\title{
Near-Infrared Mitochondria-Targetable Fluorescent Probe for High-Contrast Bioimaging of $\mathrm{H}_{2} \mathrm{~S}$
}

\author{
Shengyi Gong, Zhoupeng Zheng, Xiaogang Guan, Shumin Feng, and Guoqiang Feng* \\ Key Laboratory of Pesticide and Chemical Biology of Ministry of Education, College of Chemistry, Central China \\ Normal University, 152 Luoyu Road, Wuhan 430079, P. R. China. \\ *Corresponding author. E-mail: gf256@mail.ccnu.edu.cn.
}

Table of contents:

1. Table $\mathbf{S 1}$ Page S2-S4

2. Instruments and Materials Page S5

3. Structure Characterizations for MI-OH and MI-H $\mathrm{H}_{2} \mathrm{~S}$ Page S6-S8

4. Additional Data and Spectra Page S9-S15 
Table S1. Comparison of fluorescent probes for mitochondrial $\mathrm{H}_{2} \mathrm{~S}$.

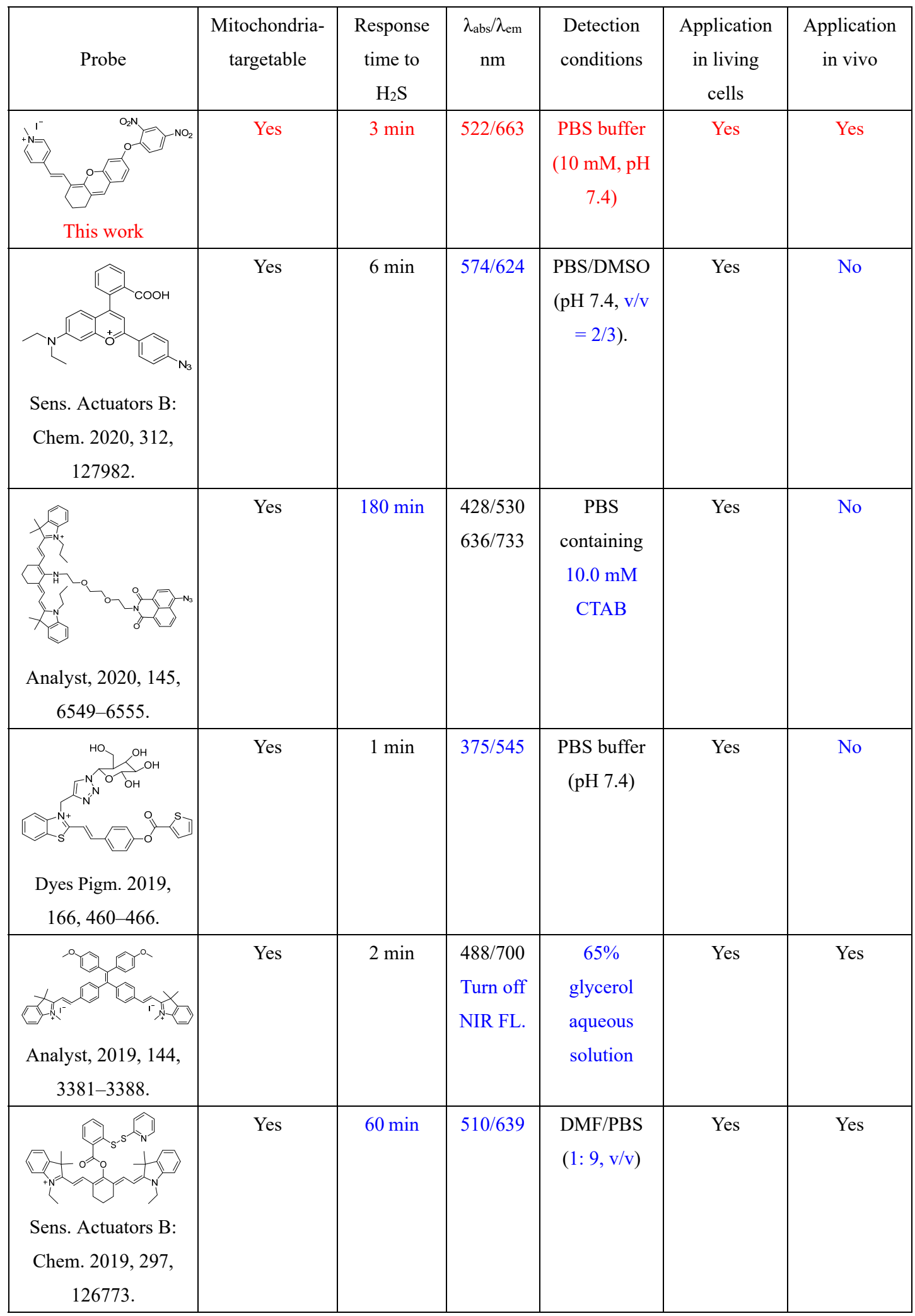




\begin{tabular}{|c|c|c|c|c|c|c|}
\hline $\begin{array}{l}\text { Sens. Actuators B: } \\
\text { Chem. 2019, 301, } \\
127116 .\end{array}$ & Yes & $30 \mathrm{~min}$ & $716 / 736$ & $\begin{array}{c}\text { HEPES- } \\
\text { EtOH buffer } \\
\text { solution } \\
(\mathrm{v}: \mathrm{v}=7: 3 \\
10 \mathrm{mM}, \mathrm{pH} \\
7.4)\end{array}$ & Yes & Yes \\
\hline Chem. Commun. & Yes & $60 \mathrm{~min}$ & $395 / 450$ & 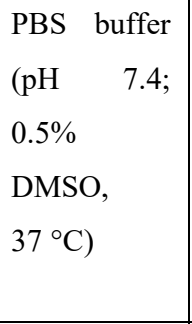 & Yes & No \\
\hline $\begin{array}{l}\text { Org. Biomol. Chem. } \\
\text { 2019,17, } \\
\text { 3389-3395. }\end{array}$ & Yes & $30 \mathrm{~min}$ & $565 / 585$ & $\begin{array}{l}\text { PBS buffer } \\
(20 \mathrm{mM}, \mathrm{pH} \\
7.4)\end{array}$ & Yes & Yes \\
\hline $\begin{array}{l}\text { Dyes Pigm. 2019, } \\
162,624-631 .\end{array}$ & Yes & $15 \mathrm{~min}$ & $530 / 565$ & $\begin{array}{l}\text { PBS buffer } \\
(20 \mathrm{mM}, \mathrm{pH} \\
7.4) \text { at } 25^{\circ} \mathrm{C}\end{array}$ & Yes & Yes \\
\hline $\begin{array}{c}\text { Anal. Chem. 2018, } \\
\text { 90, 9418-9425 }\end{array}$ & Yes & $30 \mathrm{~min}$ & $\begin{array}{l}500 / 610 \\
370 / 510\end{array}$ & $\begin{array}{l}\text { PBS buffer } \\
\text { solution }(\mathrm{pH} \\
7.4)\end{array}$ & Yes & No \\
\hline $\begin{array}{l}\text { ACS Sens. } 2018,3 \text {, } \\
992-997\end{array}$ & Yes & $20 \mathrm{~s}$ & $\begin{array}{l}650 / 710 \\
\text { Turn off } \\
\text { NIR FL. }\end{array}$ & $\begin{array}{l}\text { PBS buffer } \\
(50 \mathrm{mM}, \mathrm{pH} \\
7.4)\end{array}$ & Yes & No \\
\hline
\end{tabular}




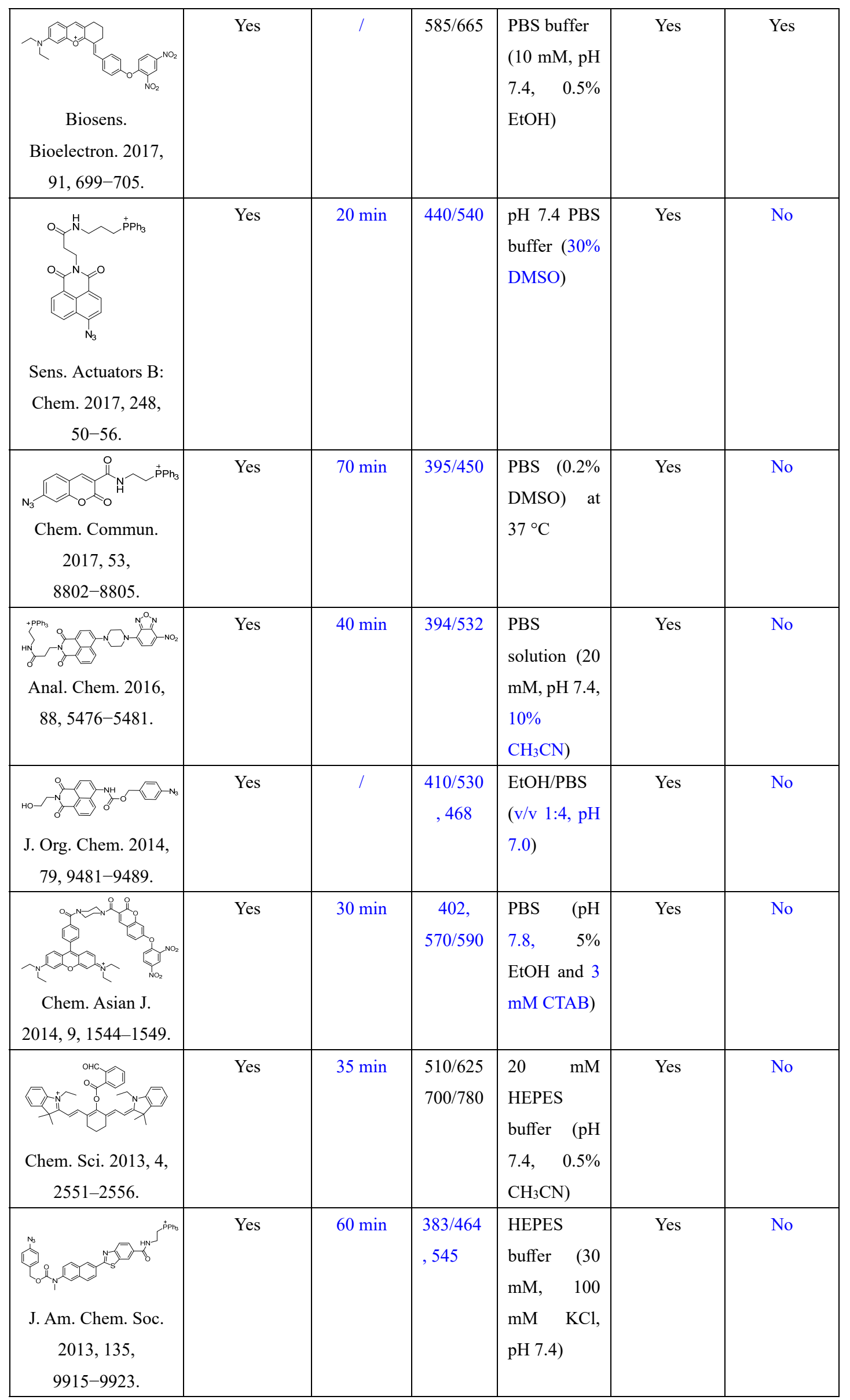




\section{Instruments and Materials.}

Unless stated otherwise, all chemicals employed in this work were purchased from commercial sources and used without any further purification. Double distilled water was used in all spectroscopic studies. ${ }^{1} \mathrm{H}$ and ${ }^{13} \mathrm{C}$ NMR spectra were recorded on a Varian 400 NMR instrument. Mass spectra were measured with a Thermo Scientific DSQ II GC/MS spectrometer and a Bruker micro TOF-Q instrument. All of the fluorescence measurements were taken on an Agilent Cary Eclipse fluorescence spectrophotometer. UV-vis absorption spectra were recorded with an Agilent Cary-100 UV-vis spectrophotometer. The fluorescence quantum yields were determined in PBS buffer $\left(10 \mathrm{mM}\right.$, pH 7.4) using cresyl violet $\left(\Phi 0.54, \mathrm{CH}_{3} \mathrm{OH}\right)$ as standard. Images of cells and zebrafish were obtained through a Leica TCS SP8 confocal fluorescence microscope. Mice imaging experiments were measured on an instrument of PerkinElmer IVIS Lumina Series III. MCF-7 cells were cultured under the condition of DMEM medium supplemented with $10 \%$ fetal bovine serum (FBS) at $37{ }^{\circ} \mathrm{C}$ in a $5 \%$ $\mathrm{CO}_{2} / 95 \%$ air incubator. Zebrafish (3 days old) were purchased from Institute of Hydrobiology, Chinese Academy of Sciences (Wuhan, Hubei province). Kunming mice $(20 \pm 2 \mathrm{~g})$ were purchased from Wuhan Center for Disease Control and Prevention and were anesthetized with tribromoethanol before imaging experiments. All experiments involving animals were approved by the Animal Ethical Experimentation Committee of Central China Normal University (CCNU). 
3. Structure Characterizations for Compounds

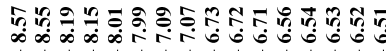

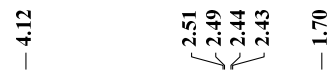

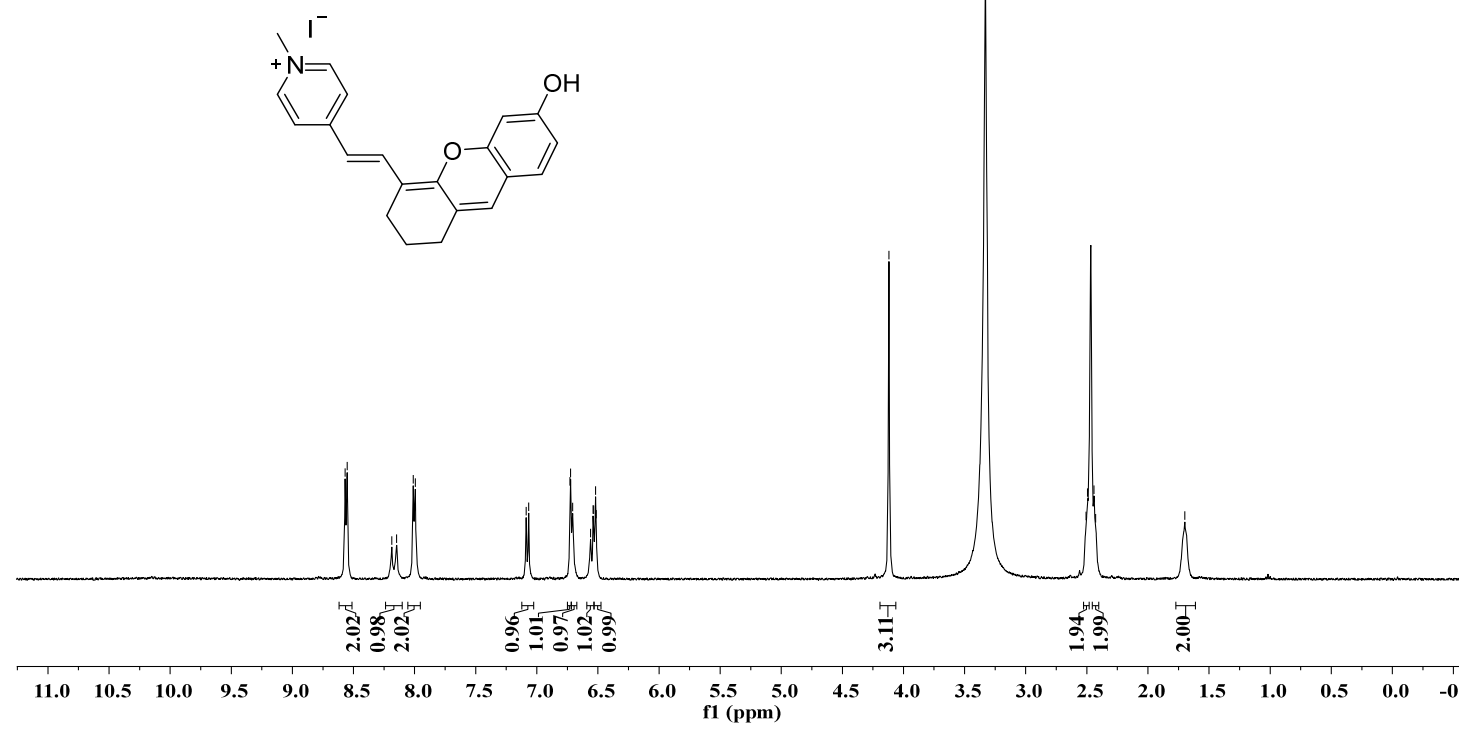

Figure S1. ${ }^{1} \mathrm{H}$ NMR spectrum of MI-OH in DMSO-d6

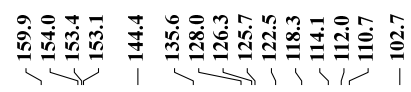

I.|ำ

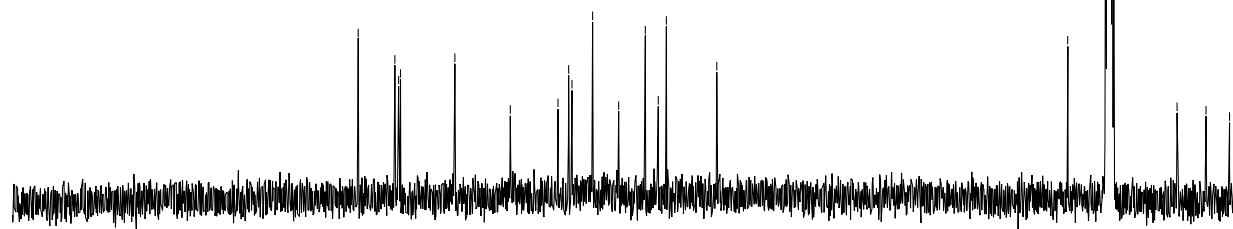

$\begin{array}{lllllllllllllllllllllll}210 & 200 & 190 & 180 & 170 & 160 & 150 & 140 & 130 & 120 & 110 & 100 & 90 & 80 & 70 & 60 & 50 & 40 & 30 & 20 & 10 & 0 & -10\end{array}$

Figure S2. ${ }^{13} \mathrm{C}$ NMR spectrum of MI-OH in DMSO-d6 


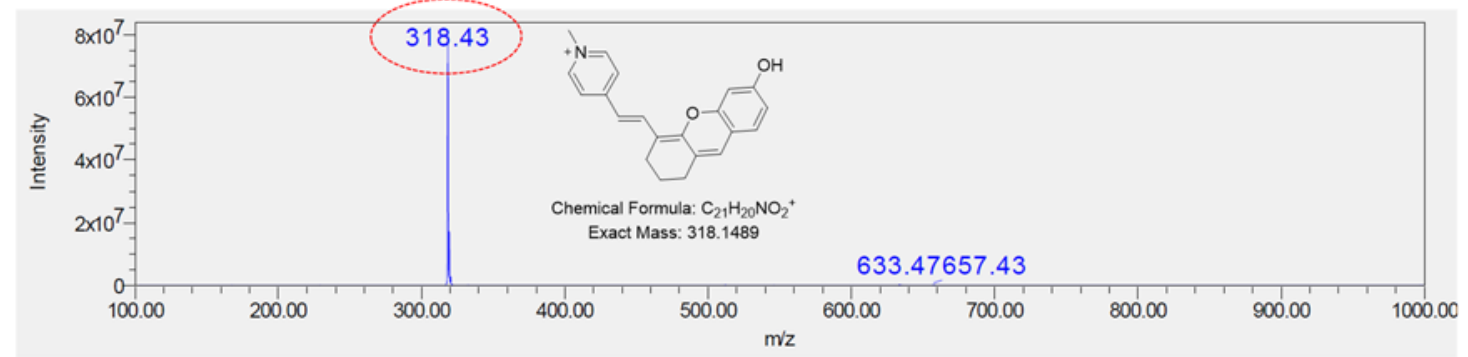

Figure S3. LC-MS spectrum of MI-OH

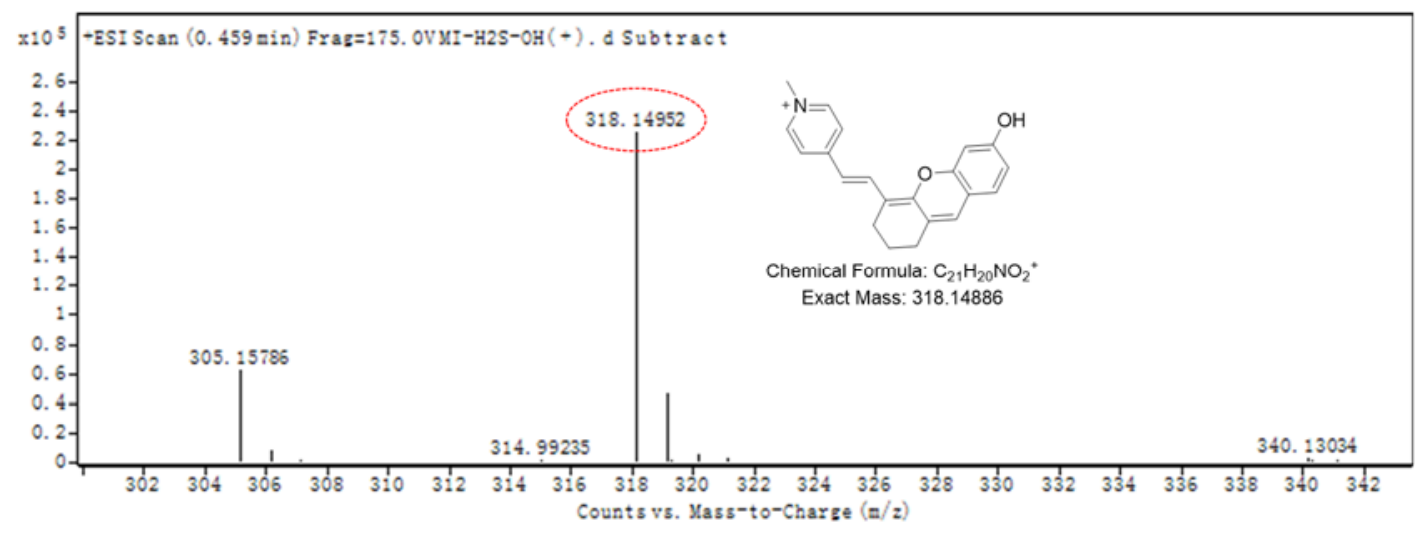

Figure S4. HR-MS spectrum of MI-OH

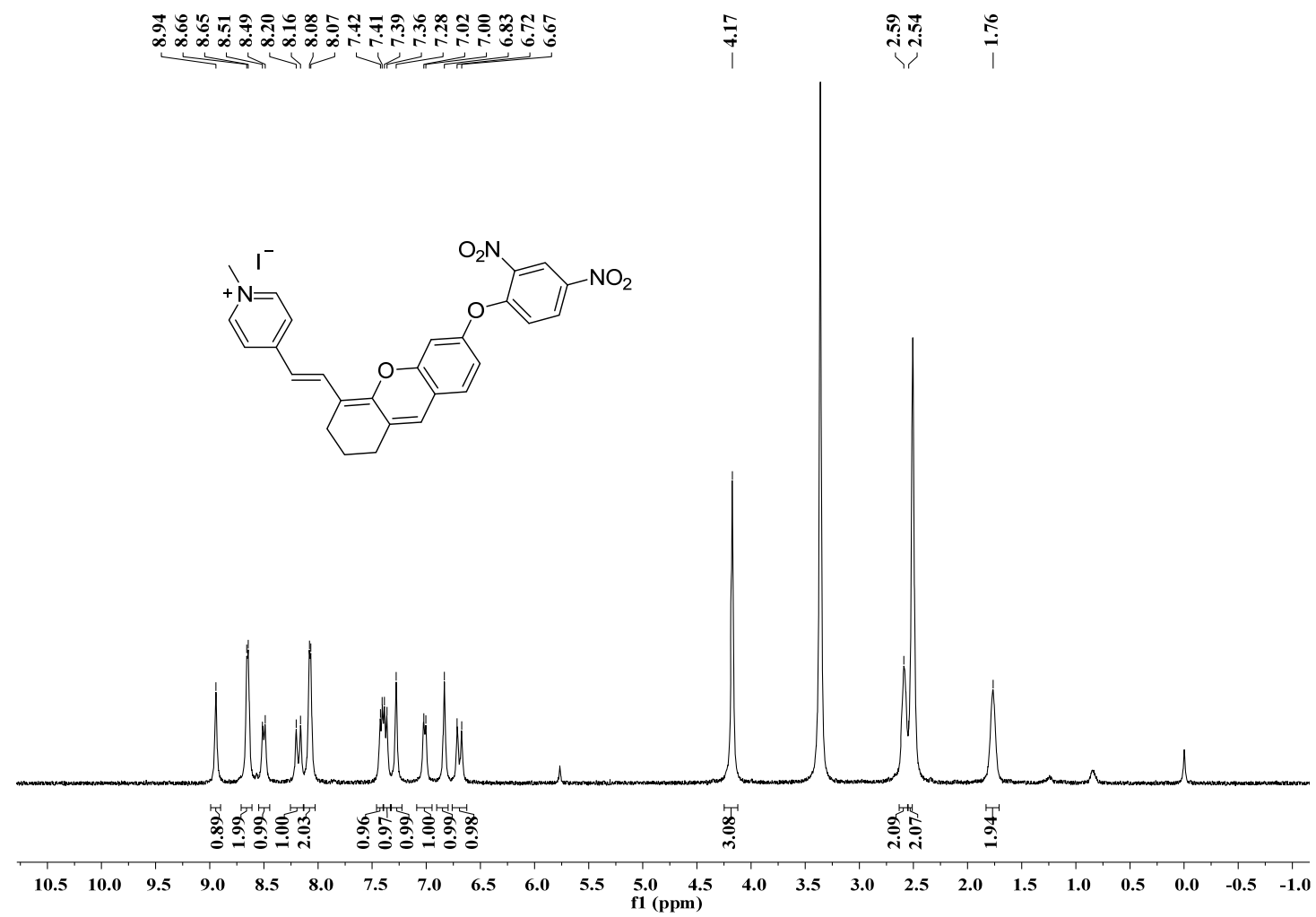

Figure S5. ${ }^{1} \mathrm{H}$ NMR spectrum of $\mathbf{M I - H} \mathbf{H}_{2} \mathbf{S}$ in DMSO-d6 


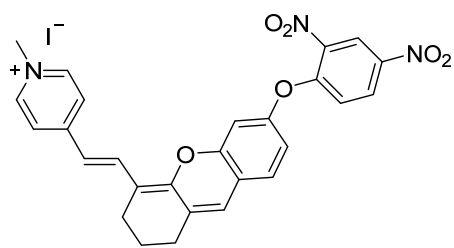

Figure S6. ${ }^{13} \mathrm{C}$ NMR spectrum of $\mathbf{M I}_{-} \mathbf{H}_{2} \mathbf{S}$ in DMSO-d6

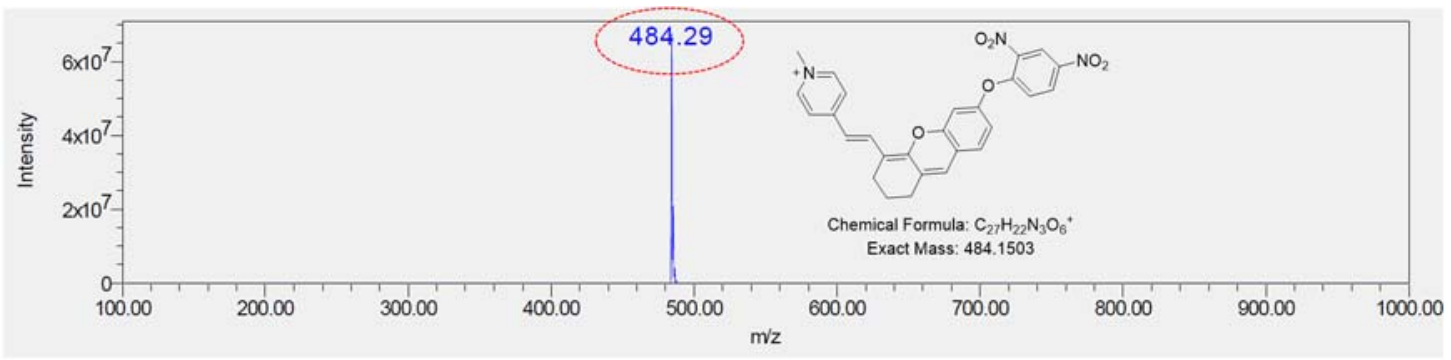

Figure S7. LC-MS spectrum of $\mathbf{M I}-\mathrm{H}_{2} \mathrm{~S}$

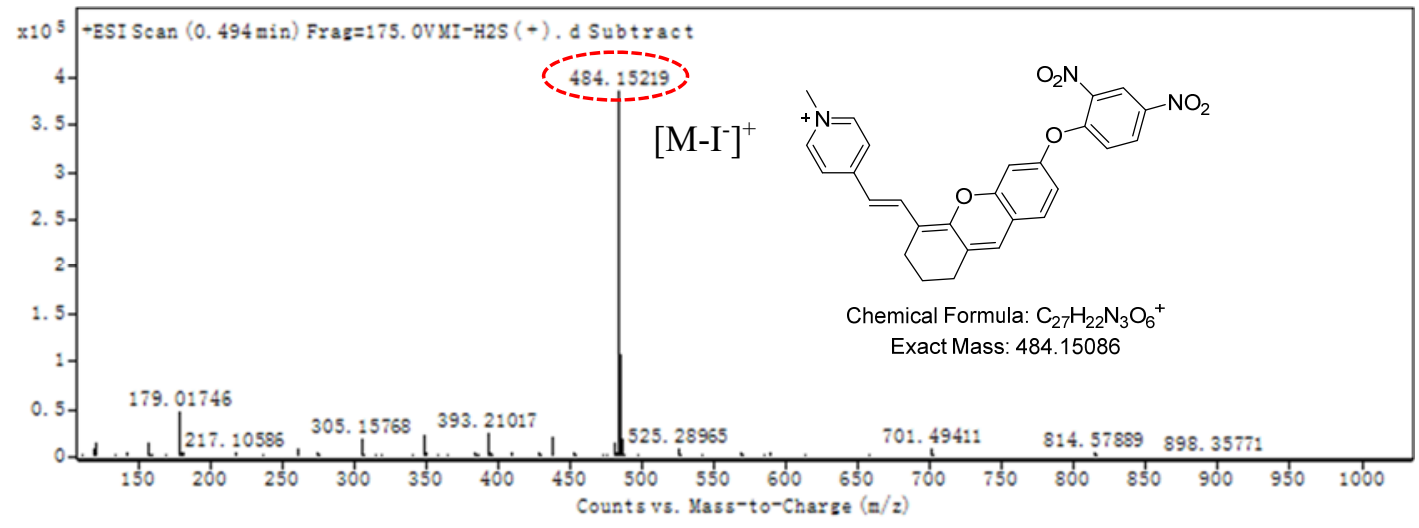

Figure S8. HR-MS spectrum of $\mathbf{M I}-\mathbf{H}_{2} \mathrm{~S}$ 


\section{Additional Data and Spectra.}

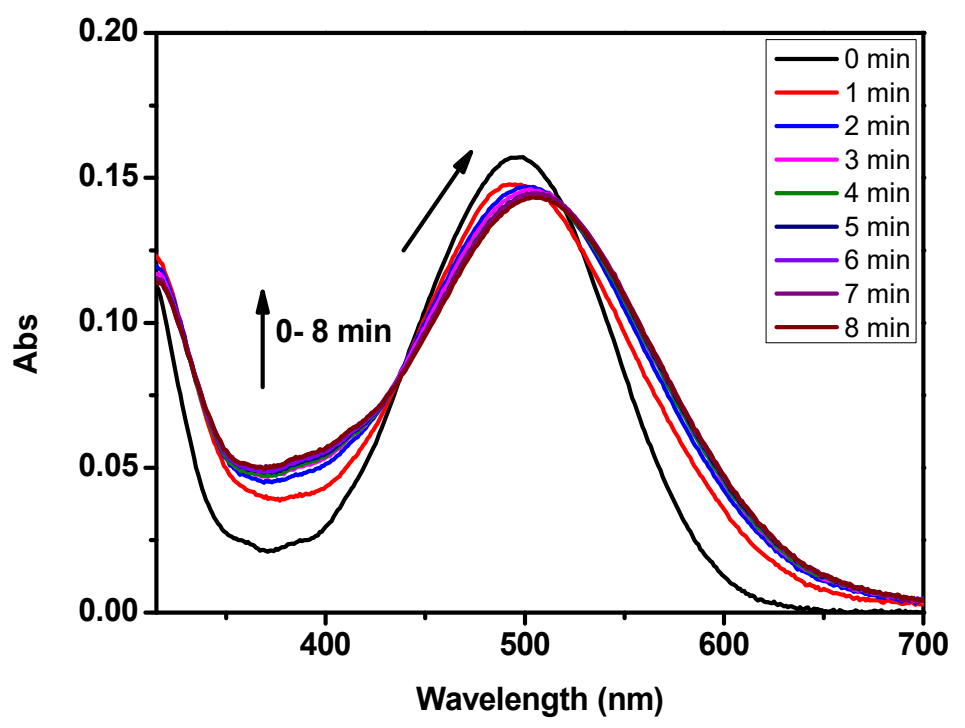

Figure S9. UV-vis spectral changes of probe $\mathbf{M I}-\mathbf{H}_{2} \mathbf{S}(10 \mu \mathrm{M})$ upon addition of $\mathrm{H}_{2} \mathrm{~S}$ $(100 \mu \mathrm{M})$. The spectra were collected in PBS buffer $(10 \mathrm{mM}, \mathrm{pH} 7.4)$ at $37^{\circ} \mathrm{C}$.

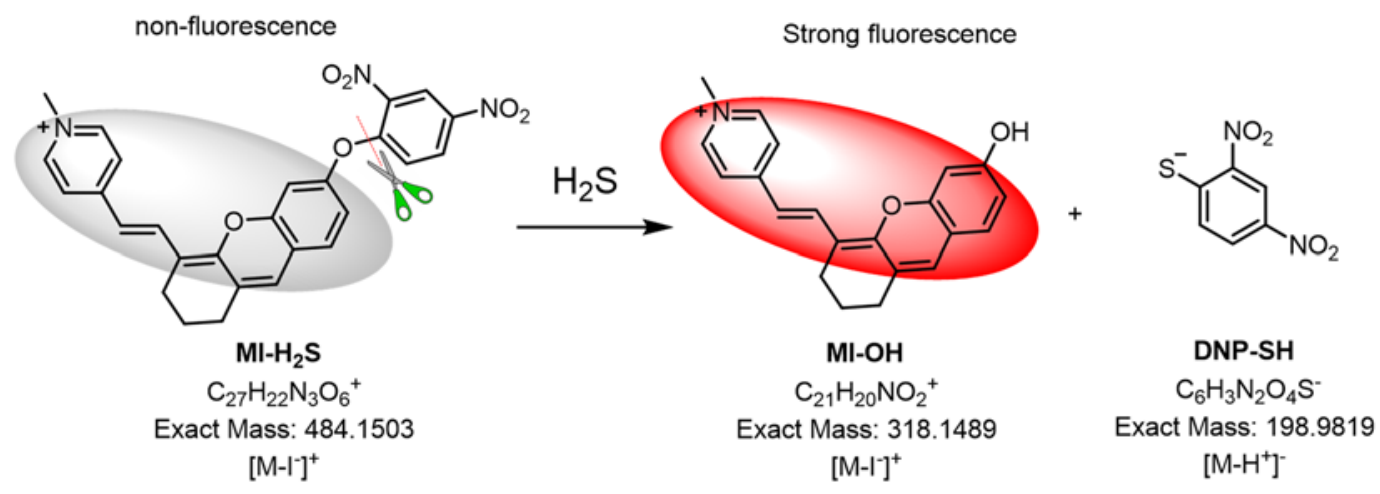

Scheme S1. The proposed sensing mechanism of $\mathbf{M I}-\mathrm{H}_{2} \mathrm{~S}$ for detection of $\mathrm{H}_{2} \mathrm{~S}$. 


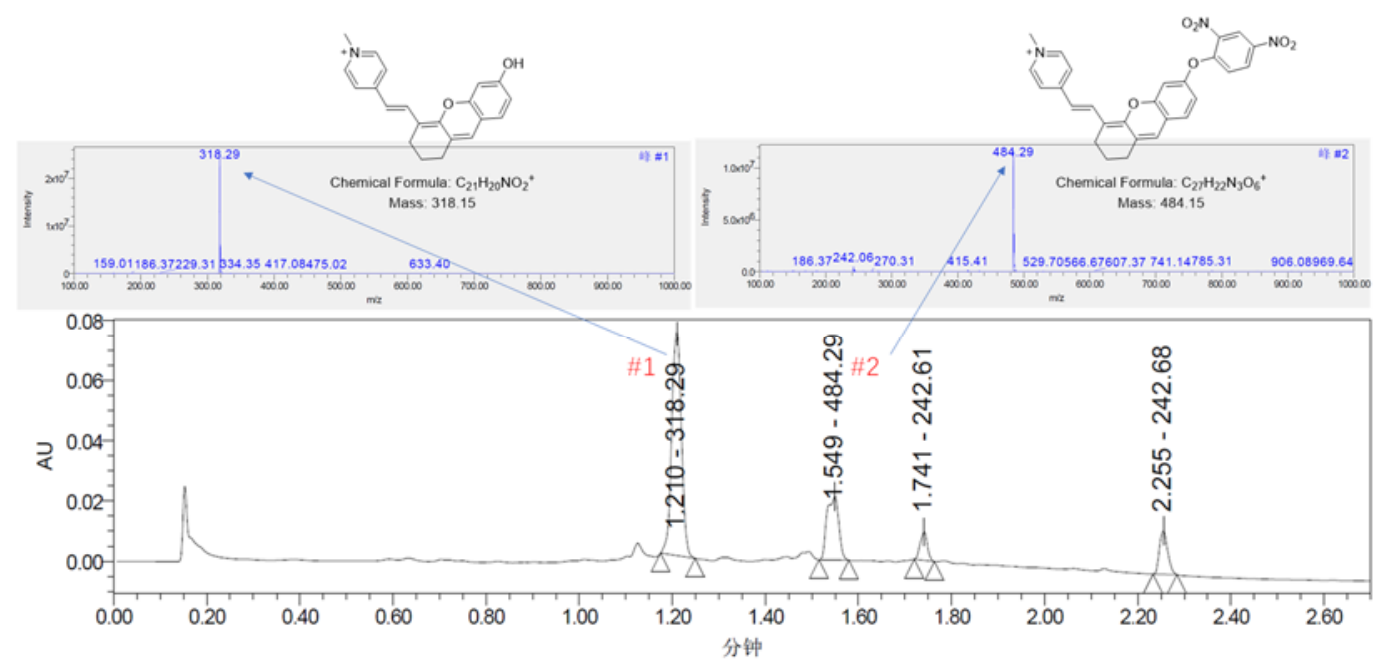

(a) Positive mode
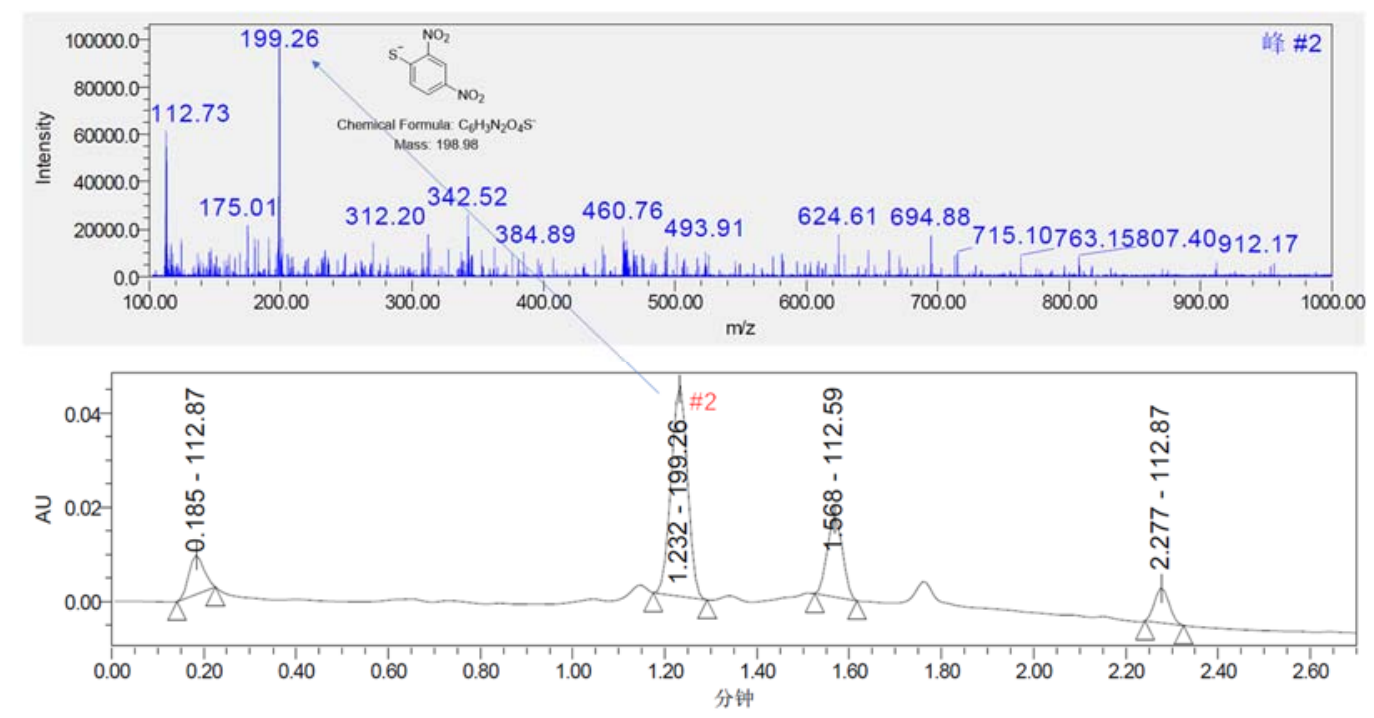

(b) Negative mode

Figure S10. Low resolution mass spectrum of the reaction mixture of the probe $(10 \mu \mathrm{M}$ MI-H 2 S) with $\mathrm{H}_{2} \mathrm{~S}(50 \mu \mathrm{M})$ in PBS buffer $(10 \mathrm{mM}$, pH 7.4). The spectra of (a) positive mode and (b) negative mode were taken after the mixture was incubated for 15 min at room temperature. The peak at $\mathrm{m} / \mathrm{z}=318.29$ can be assigned to be $\mathbf{M I - O H}$ (calcd. 318.15), peak at $\mathrm{m} / \mathrm{z}=484.29$ can be assigned to be $\mathbf{M I - H _ { 2 }} \mathbf{S}$ (calcd. 484.15), and the peak at $\mathrm{m} / \mathrm{z}=199.26$ can be assigned to be 2,4-dinitrobenzenethiolate (calcd. 198.98). 

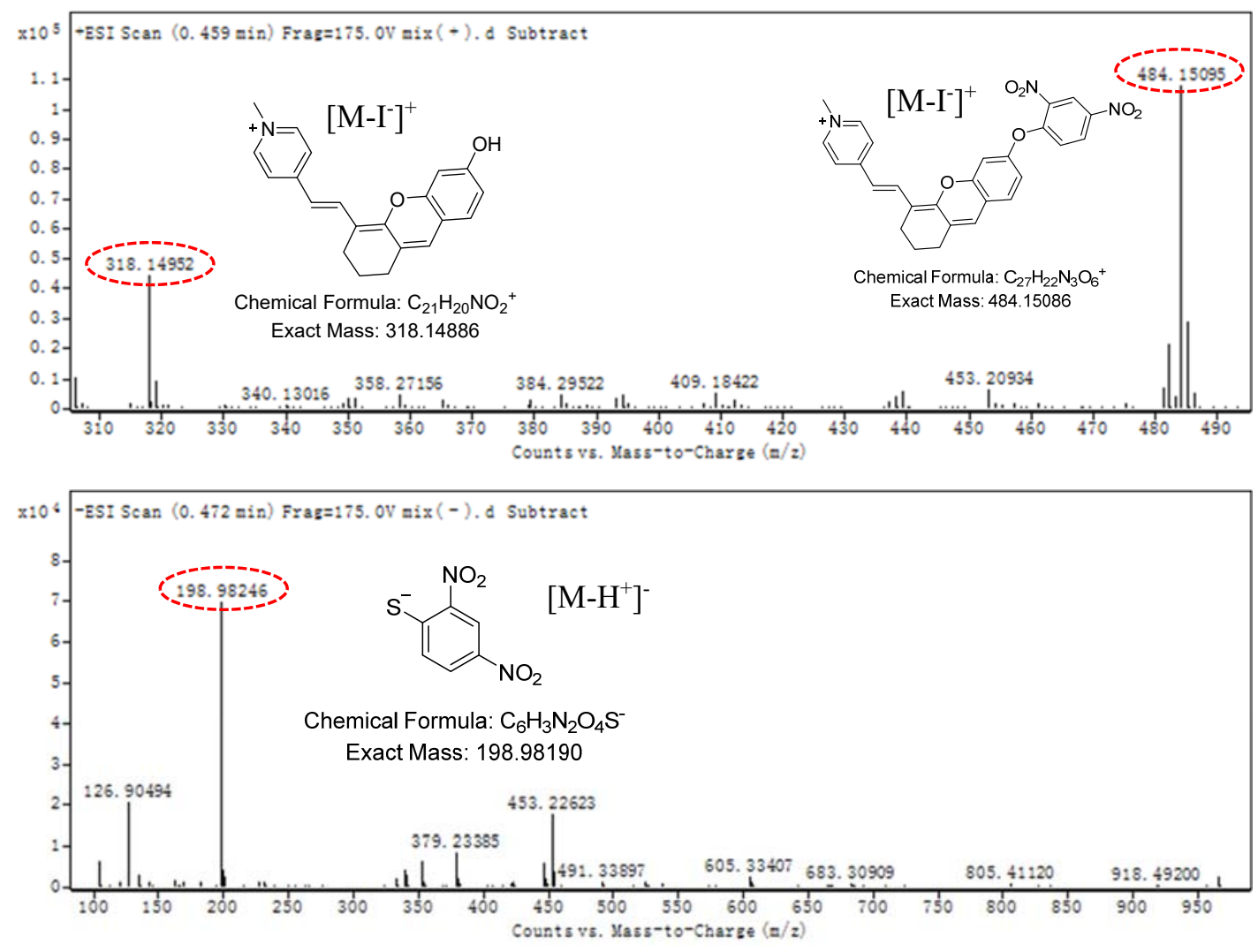

Figure S11. High resolution mass spectrum (HR-MS) of the reaction mixture of the probe $\left(10 \mu \mathrm{M}\right.$ MI-H $\left.-\mathbf{H}_{2} \mathbf{S}\right)$ with $\mathrm{H}_{2} \mathrm{~S}(50 \mu \mathrm{M})$ in PBS buffer $(10 \mathrm{mM}, \mathrm{pH} 7.4)$. The spectrum was taken after the mixture was incubated for $15 \mathrm{~min}$ at room temperature. The peak at $\mathrm{m} / \mathrm{z}=318.14952$ can be assigned to be MI-OH (calcd. 318.14886), peak at $\mathrm{m} / \mathrm{z}=484.45095$ can be assigned to be $\mathbf{M I}-\mathbf{H}_{2} \mathbf{S}$ (calcd. 484.15086), and the peak at $\mathrm{m} / \mathrm{z}=198.98246$ can be assigned to be DNP-SH (calcd. 198.98190).

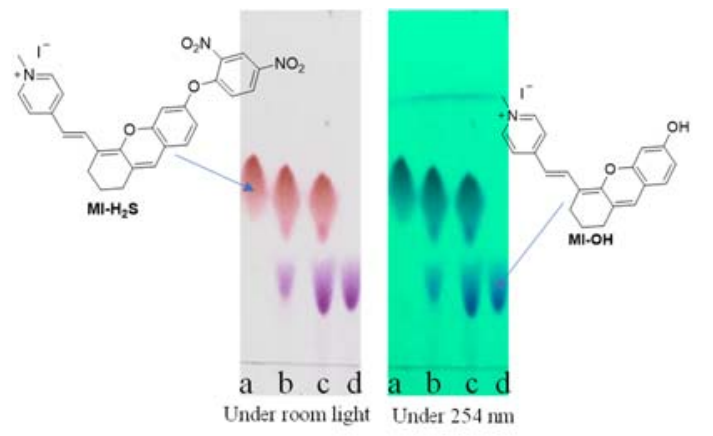

Figure S12. TLC analysis (mobile phase: $\mathrm{CH}_{2} \mathrm{Cl}_{2}: \mathrm{CH}_{3} \mathrm{OH}=10: 1, \mathrm{v} / \mathrm{v}$ ). Sample spotted in the TLC plate: a. MI-H $\mathbf{2}$ S. b. The reaction mixture of $\mathbf{M I}_{-}-\mathbf{H}_{2} \mathbf{S}$ and NaHS. c. The mixture of $b$ and d. d. Reference of MI-OH. 
(a)
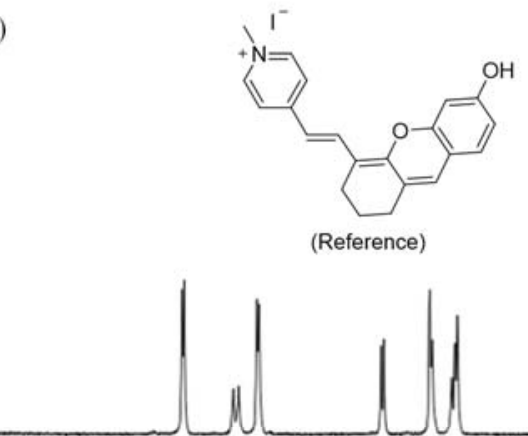

(b)

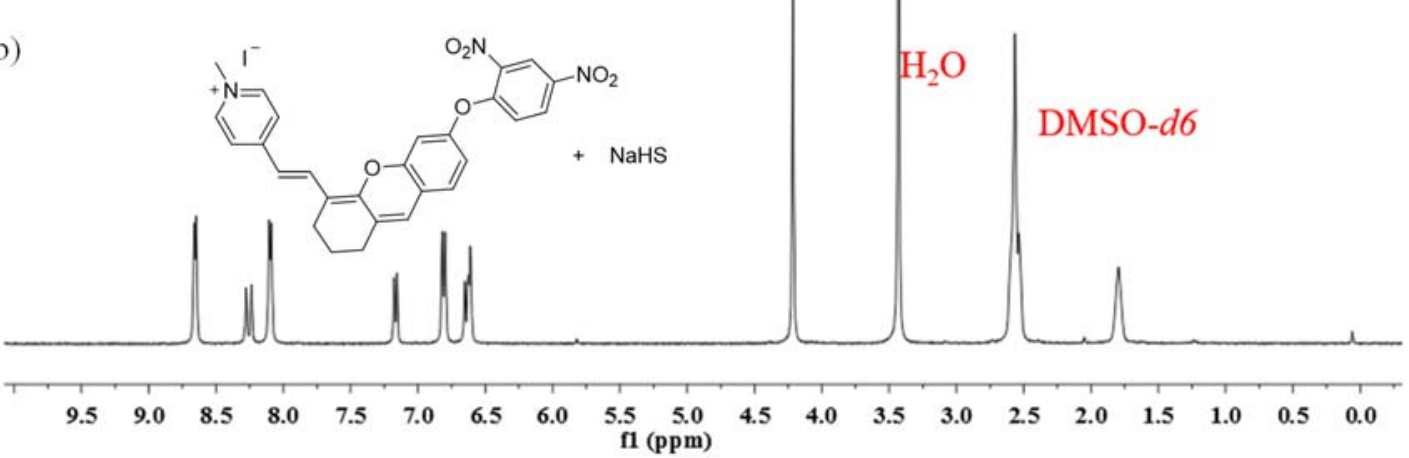

Figure S13. (a) ${ }^{1} \mathrm{H}$ NMR spectrum of MI-OH. (b) ${ }^{1} \mathrm{H}$ NMR spectrum of the isolated product from the reaction of the probe $\mathbf{M I}-\mathbf{H}_{2} \mathbf{S}(50 \mathrm{mg}, 0.08 \mathrm{mmol})$ with NaHS (10 equiv.) in $10 \mathrm{~mL}$ PBS buffer (10 mM, pH 7.4, with $1 \mathrm{~mL}$ DMSO).

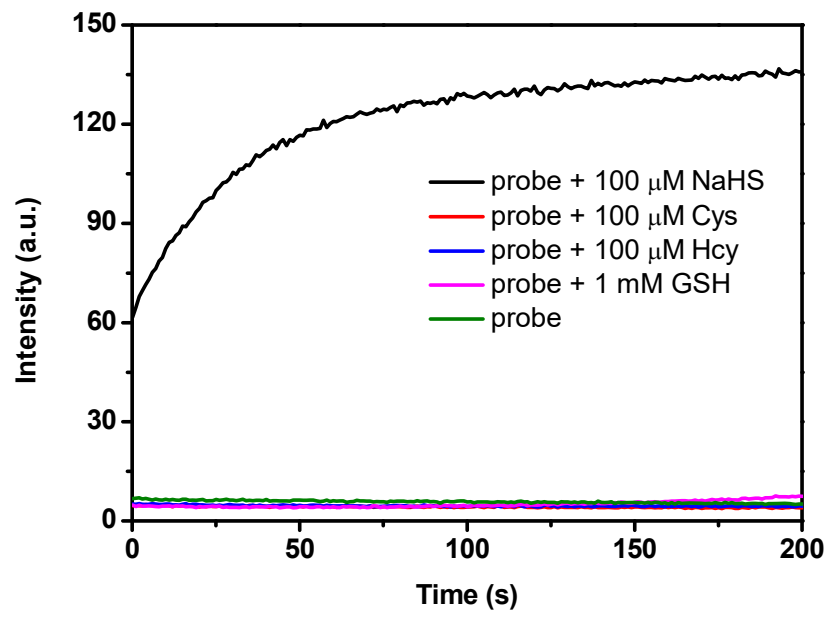

Figure S14. Fluorescence kinetics of probe $\mathbf{M I}-\mathrm{H}_{2} \mathbf{S}(10 \mu \mathrm{M})$ upon addition of NaHS and biothiols (Cys, Hcy, and GSH). All data were monitored at $663 \mathrm{~nm}$ in PBS buffer $(10 \mathrm{mM}, \mathrm{pH} 7.4)$ at $37^{\circ} \mathrm{C} \cdot \lambda_{\mathrm{ex}}=530 \mathrm{~nm}$. 


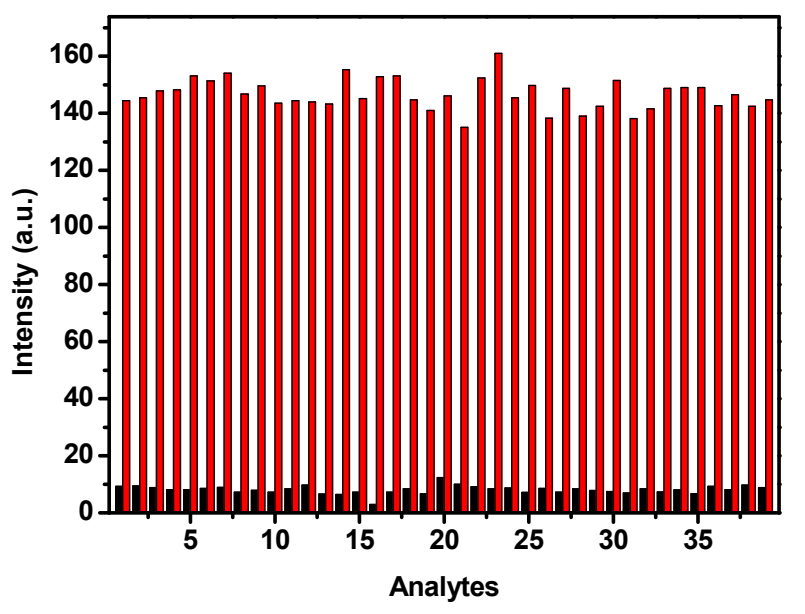

Figure S15. Fluorescent intensity responses of probe $\mathbf{M I}-\mathrm{H}_{2} \mathbf{S}(10 \mu \mathrm{M})$ at $663 \mathrm{~nm}$ to NaHS $(100 \mu \mathrm{M})$ in the presence of various analytes (100 $\mu \mathrm{M}$ unless otherwise stated) including: (1) $\mathrm{K}^{+}$, (2) $\mathrm{Na}^{+}$, (3) $\mathrm{NH}_{4}^{+}$, (4) $\mathrm{F}^{-}$, (5) $\mathrm{Cl}^{-}$, (6) $\mathrm{Br}^{-}$, (7) $\mathrm{I}^{-}$, , (8) $\mathrm{NO}_{3}{ }^{-}$, (9) $\mathrm{C}_{2} \mathrm{O}_{4}{ }^{2-}$, (10) $\mathrm{S}_{2} \mathrm{O}_{7}{ }^{2-}$, (11) $\mathrm{SO}_{3}{ }^{2-}$, (12) $\mathrm{HSO}_{3}{ }^{-}$, (13) $\mathrm{HSO}_{4}{ }^{-}$, (14) $\mathrm{AcO}^{-}$, (15) $\mathrm{HCO}_{3}{ }^{-}$, (16) $\mathrm{N}_{3}^{-}$, (17) $\mathrm{SCN}^{-}$, (18) His, (19) Pyr, (20) Phe, (21) Glu, (22) Arg, (23) Ile, (24) Lys, (25) Ala, (26) Val, (27) Asp, (28) Tyr, (29) Leu, (30) Trp, (31) Met, (32) Gln, (33) Ser, (34) Thr, (35) Gly, (36) Hcy, (37) Cys, (38) $1 \mathrm{mM} \mathrm{GSH}$, (39) none. Black bars represent the addition of a single analyte. Red bars represent the subsequent addition of NaHS (100 $\mu \mathrm{M})$ to the mixture. All data were collected in PBS buffer $(10 \mathrm{mM}, \mathrm{pH} 7.4)$ at $37^{\circ} \mathrm{C}$. $\lambda_{\mathrm{ex}}=530$ nm.

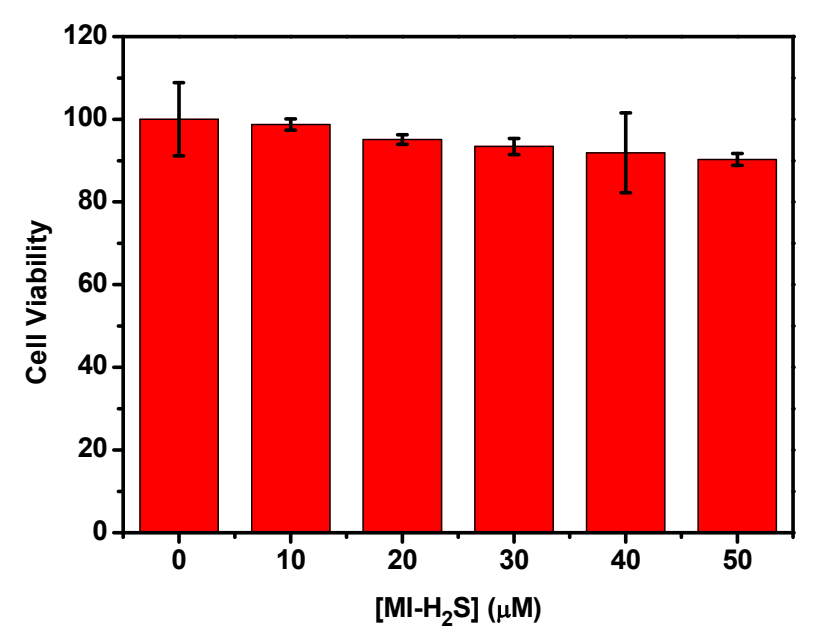

Figure S16. The percentage of viable MCF-7 cells after treatment with different concentrations of MI-H2S after 24 hours. The cell viability was obtained via MTT assay. 


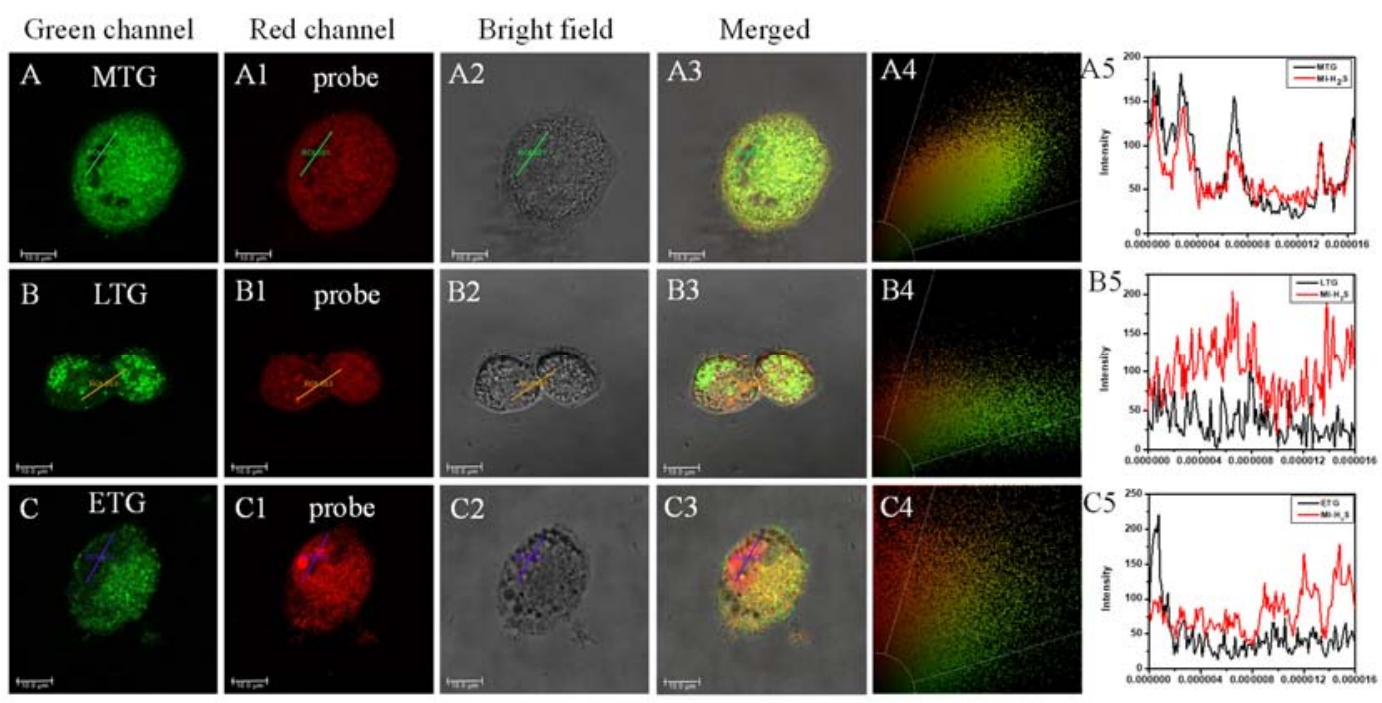

Figure S17. Data of colocalization imaging of probe $\mathbf{M I - H _ { 2 }}$ S/NaHS with (A) MTG, (B) LTG, and (C) ETG in MCT-7 cells. Green channel: $\lambda_{\mathrm{ex}}=488 \mathrm{~nm}, \lambda_{\mathrm{em}}=500-550$ nm. Red channel: $\lambda_{\mathrm{ex}}=561 \mathrm{~nm}, \lambda_{\mathrm{em}}=600-800 \mathrm{~nm}$. (A1)-(C1): Red channel images. (A2)-(C2): Bright field images. (A3)-(C3): Merged images. (A4, B4, and C4) Plot of intensity scatter of green and red channels. (A5, B5, and C5): The intensity profile of linear regions of interest (ROI) across the cells.
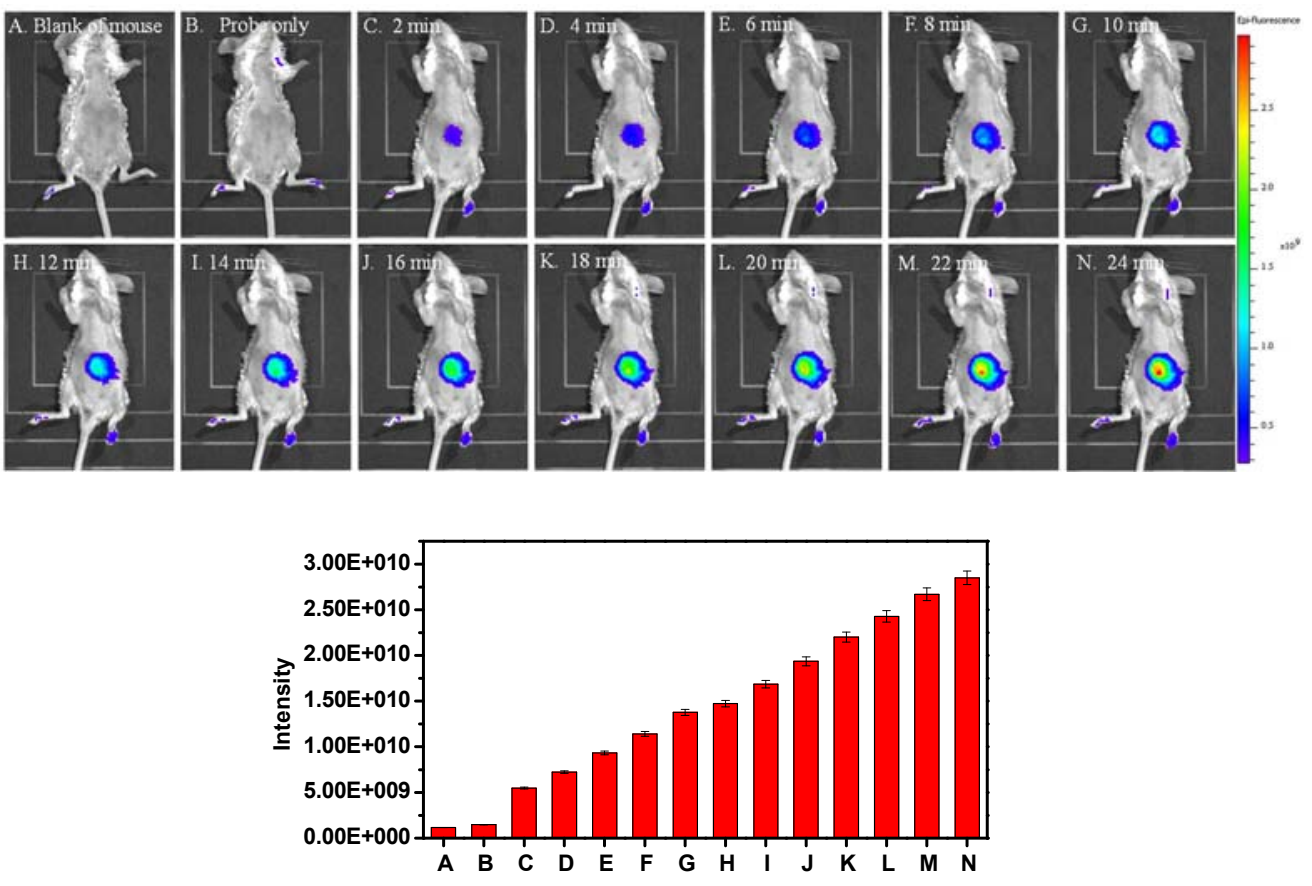

Figure S18. Imaging of $\mathrm{H}_{2} \mathrm{~S}$ in living mice with probe $\mathbf{M I - H _ { 2 }} \mathbf{S}$ over time. (A) Blank of mouse. (B) Blank of probe MI-H2S. (C-N) Mouse was given an intraperitoneal 
injection of NaHS (10 equiv) followed by injection with $\mathbf{M I}-\mathbf{H}_{2} \mathbf{S}$ and the mouse was imaged every $2 \mathrm{~min}$ within $24 \mathrm{~min}$. The bottom figure shows the relative fluorescence intensity from the abdominal area of the mice at different times in the images of A-N. Excitation was set at $540 \mathrm{~nm}$ and emission was collected at $670 \mathrm{~nm}$.

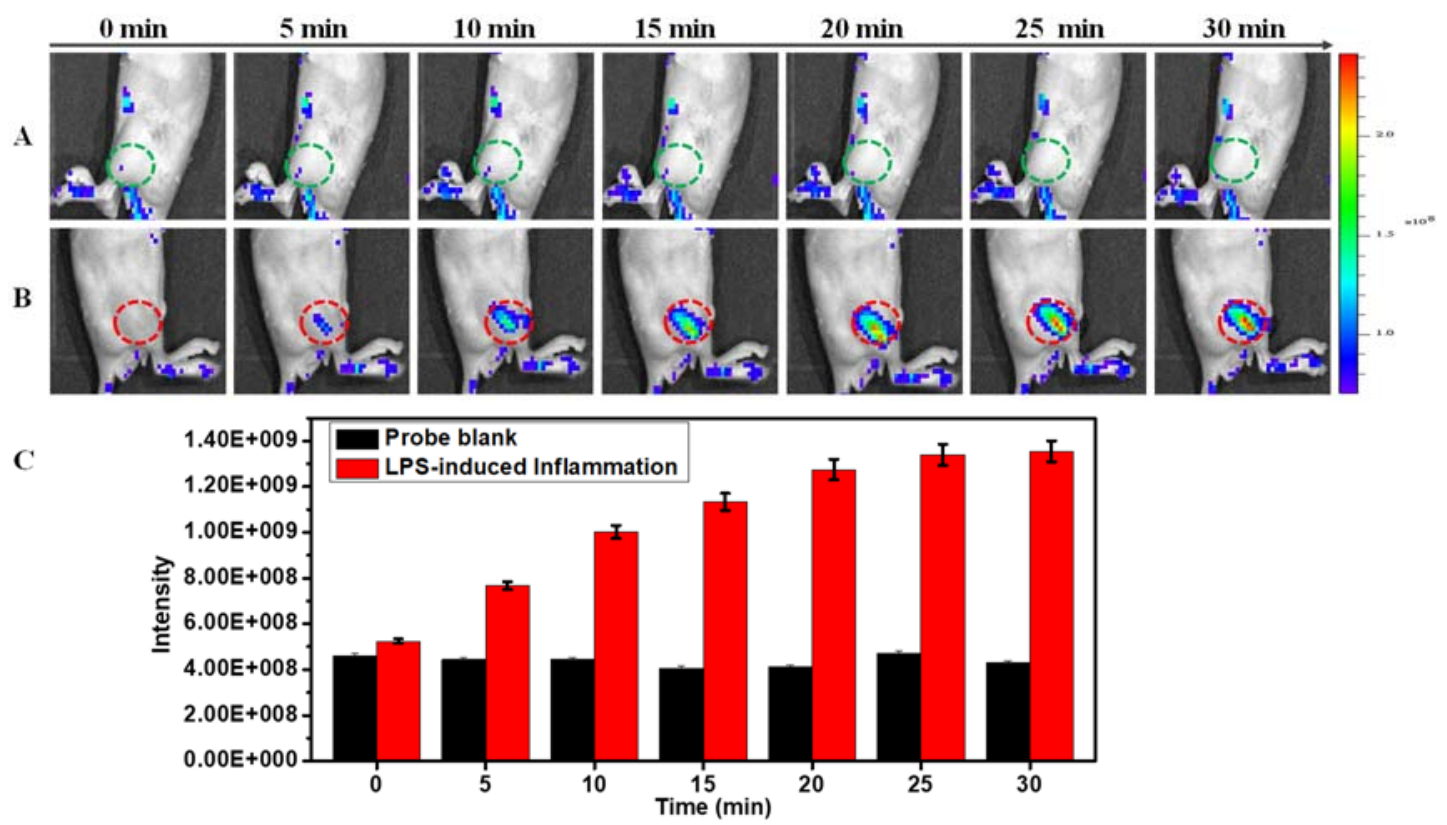

Figure S19. Imaging of $\mathrm{H}_{2} \mathrm{~S}$ in LPS-induced mouse leg inflammation. (A) Probe blank as control group: mice rear legs were subcutaneously injected with $50 \mu \mathrm{L}$ of $0.1 \mathrm{mM}$ MI-H $\mathbf{H}_{2} \mathrm{~S}$ and then imaged every $5 \mathrm{~min}$. (B) Mice rear legs were subcutaneously injected $50 \mu \mathrm{L}$ of $2.0 \mathrm{mg} / \mathrm{mL}$ LPS for $8 \mathrm{~h}$ to cause inflammation and after that, $50 \mu \mathrm{L}$ of $0.1 \mathrm{mM}$ $\mathbf{M I}-\mathbf{H}_{2} \mathbf{S}$ was subcutaneously injected in the inflammatory area and then the mice were imaged every 5 min. (C) Fluorescence quantification data of group A and B. $\lambda_{\mathrm{ex}}=540$ $\mathrm{nm}, \lambda_{\mathrm{em}}=670 \mathrm{~nm}$. 